\title{
Suicide risk in systemic lupus erythematosus: a narrative review
}

\author{
Risco de suicidio no lúpus eritematoso sistêmico: uma revisão narrativa
}

\author{
Solange Murta Barros ${ }^{1 *}$, Danilo Barral de Araújo², Jozélio Freire de Carvalho . $^{3}$ \\ ${ }^{1}$ Marinha do Brasil, Centro de Instrução "Almirante Wandenkolk", Rio de Janeiro-RJ; ${ }^{2}$ Professor Doutor Associado \\ de Bioquímica Oral e do Programa de Pós-graduação em Processos Interativos dos Órgãos e Sistemas da UFBA \\ ${ }^{3}$ Instituto de Ciências da Saúde, Universidade Federal da Bahia, Salvador-BA
}

\begin{abstract}
Introduction: the restrictions imposed by the disease and the perception of personal and social losses related to its course, despite the medical and scientific advances, reinforce fear and generate intense suffering in lupus patients. Psychiatric comorbidities, especially major depressive episodes, are highly prevailing during the course of systemic lupus erythematosus. Among them, suicide is a behavior that is much more common then we believe. Objective: to perform a narrative review on suicidal behavior associated with systemic erythematosus lupus (SLE). Results: studies have shown an increased risk of suicide among patients with chronic diseases and psychiatric disorder, especially depression. However, suicide occurrence cannot be attributed only to a higher prevalence of depression and other mental illnesses. It is necessary to learn more about the suicide risk factors that can be present in patients with lupus to work on a secondary prevention, and avoid not only the premature loss of lives but also the additional suffering of families and surrounding communities. The coordination between the studies on suicidal behavior and its complex network of individual and sociocultural factors and the studies on this multisystem autoimmune disease with a wide manifestation spectrum, which is lupus, creates a new and important field of research. Conclusion: non-psychiatrist office-based physicians, health clinics, or wards dedicated to the treatment of SLE should be able to recognize and handle the suicide risk factors on their patients in order to reduce the suffering caused by this disease.
\end{abstract}

Keywords: Lupus Erythematosus, Systemic. Nervous System Diseases. Mental Disorders. Suicidal Ideation. Suicide.

\begin{abstract}
Resumo
Introdução: as restrições impostas pela doença e a percepção de perdas pessoais e sociais relacionadas ao seu curso, apesar dos avanços médicos e científicos, reforçam o medo e geram sofrimento intenso em pacientes com lúpus. As comorbidades psiquiátricas, especialmente os episódios depressivos maiores, são altamente prevalentes durante o curso do lúpus eritematoso sistêmico. Entre eles, o suicídio é um comportamento muito mais comum do que acreditamos. Objetivo: realizar uma revisão narrativa sobre o transtorno do suicídio no campo do lúpus. Resultados: estudos têm mostrado um risco aumentado de suicídio entre pacientes com doenças crônicas e distúrbios psiquiátricos, especialmente a depressão. No entanto, a ocorrência de suicídio não pode ser atribuída apenas a uma maior prevalência de depressão e outras doenças mentais. É necessário aprender mais sobre os fatores de risco de suicídio que podem estar presentes em pacientes com lúpus para trabalhar em uma prevenção secundária e evitar, não apenas a perda prematura de vidas, mas também o sofrimento adicional das famílias e comunidades vizinhas. A coordenação entre os estudos sobre comportamentos suicidas e sua complexa rede de fatores individuais e socioculturais e os estudos sobre esta doença auto imune multissistêmica com um amplo espectro de manifestação, que é lúpus, criam um novo e importante campo de pesquisa. Conclusão: os médicos não psiquiatras que trabalham em consultórios, clínicas e enfermarias dedicadas ao tratamento do lúpus devem ser capazes de pesquisar, identificar e lidar com os fatores de risco suicida em seus pacientes, a fim de reduzir o sofrimento causado por esta doença.

Palavras-chave: Lúpus Eritematoso Sistêmico. Doenças do Sistema Nervoso Central. Transtorno mental. Ideação suicida. Suicídio.
\end{abstract}

\section{INTRODUCTION}

Semantically, suicide is defined as a self-inflicted death performed by an individual who is conscious of its consequences, and its frequency is usually under-reported due to cultural influences. It is a complex behavior process that comprises suicidal ideation, planning, attempts, and fatal acts ${ }^{1,2}$.

Although human beings are, by nature, attached to their survival instinct and are afraid of death, some of

Correspondente/Corresponding: *Solange Murta Barros - End: Barão de São Borja Street, 17 apartment 906 - Méier - Rio de Janeiro/RJ, Brazil. Postal code: 20720300 - Telephone: +55-21-98754-1658 - Email: solmurta@gmail.com them consider death an alternative to relieve or solve their problems, in contrast to the perspective of a painful life, which can lead to a suicidal behavior ${ }^{3,4}$.

Among chronically ill patients (e.g. painful syndromes associated to cancer and HIV), mortality is estimated to be four times greater than in the general population, and even higher when associated to a psychiatric disorder, especially depression ${ }^{1,5-7}$.

Systemic Lupus Erythematosus (SLE) is a chronic autoimmune disease with a wide clinical manifestation spectrum, and it includes neuropsychiatric syndromes that can vary from moderate emotional disorders to greater depression episodes and severe psychosis ${ }^{10,12-14}$. 
The restrictions imposed, and the perception of losses related to the course of this disease, despite the medical and scientific advances, reinforce fear and generate intense physical and psychological suffering in lupus patients. In several cohort studies of SLE, suicide is a self-destructive event more frequent than usually believed, emphasizing that suicidal ideation and planning in lupus patients increased in the presence of psychiatric comorbidities, reaching a risk of up to five times higher than the average risk in the population ${ }^{1,11}$.

Most series studies of patients with lupus estimate the frequency of suicide attempts between $8.3 \%$ and $12.4 \%^{9-14}$. Differently, a single study reported a frequency of up to $34.4 \%$ of ongoing suicidal ideation in a group of Chinese patients with lupus, in which case the authors associate it to financial problems, family breakdown, beliefs, and psychological conditions (prior to the disease) associated to the negative manner of facing the crisis ${ }^{15}$.

The objective of this article is to perform a narrative review on suicide and SLE.

\section{Risk and Protective Factors}

The literature demonstrates that unemployed people, especially when they are the family's main provider, and those who live under the government's financial aid, are more prone to commit suicide $e^{4,14,16,17}$. Whereas the social cohesion manifested by belonging to social stable groups, like religious and work institutions, therapeutic support groups, strong family bonds, as well as the support from caregivers and friends is known as the main environmental protective factor against suicide tendencies ${ }^{12-15}$.

Therefore, people with a low level of education, poor economic situation, social isolation stigmas and belonging to family groups dismantled by divorce, recently widowed, abandoned or mistreated, who cease being engaged in any social activity in the community start to exhibit the risk of developing suicidal behavior ${ }^{1,5,16,17}$.

There are controversial data about genetic disposition to self-destructive behavior, since it is difficult to exclude from the analysis the influence of severe psychological trauma, associated to suicide history in the family ${ }^{5-7}$.

Regarding sex, males usually have higher mortality related to suicide, while a greater number of attempts are associated to females. Infertility, sexual dysfunctions, and gender dysphoria can also be inciting conflicts for suicidal ideation. Sex also affects the choice of methods, while men usually prefer the use of firearms, hanging, or jumping from high places, women prefer to use gas asphyxiation, drug intoxication, and in rural environments insecticide and rat poison ${ }^{6,7,14}$.

The age range of greater risks are, universally, elderly and young adults. Among the elderly, the occurrence of chronic and progressive diseases and neuropsychiatric comorbidities with cognitive changes are considered related factors. Among young adults, the factors are immaturity, impulsivity, aggressiveness, and the use of psychoactive drugs s, $5,18,19^{\text {. }}$

The theory that prevails is that almost all the suicide cases are related to a previous psychiatric imbalance, capable of distorting reality along with feelings of despair, abandonment and desperation, which ends in a suicide attempt ${ }^{11,16}$.

On the one hand, depression, alcohol and substance abuse are frequent in people who commit suicide; on the other hand, concerning to mental illnesses, people with bipolar disorders, schizophrenia, and antisocial and borderline personality disorders are more prone to commit suicide. The risk increases directly according to the negative symptoms and the degree of functional repercussion, and not due to the exuberance of the productive symptoms. The most impacted are not the mentally ill, but the ones with well-functioning minds prior to the disease, with critical judgment to notice the impact of the psychiatric disease and are pessimist about the outcome of the treatment $t^{5,7,12,13}$.

There are researchers who try to implicate low serotonin concentration in the central nervous system as suicide markers, but it is more likely to signal an underlying depression. However, digressing for a moment, if suicide can be considered the devastating consequence of depression, it is also possible that the torturing suicidal ideation can be the cause, or worsening factors, of the same depression $^{9,10}$.

Prescribing lithium for bipolar disorders and clozapine for schizophrenia are the chosen therapeutic schemes to reduce the risk of suicide, since they act controlling impulsivity and aggressiveness ${ }^{20-22}$. However, many continued use psychotropic drugs have been reported as inducing suicidal behavior, like benzodiazepines, narcotic analgesics, and anticonvulsants, in elderly people, and serotonin receptor blockers, appetite suppressants, and hallucinogenic drugs in teenagers ${ }^{18,23,24}$.

There are warnings that some non-psychoactive drugs can have as side effect suicidal ideation, like efavirenz, an antiretroviral used in HIV treatment, and isotretinoin, used in skin care treatments in teenagers and young adults with acne.25, 26 .

With respect to corticosteroids, used in high dosage for treating neuropsychiatric conditions in lupus patients, although they can be related to psychotic breaks, and there is some controversy in the literature whether it is indifferent or can increase the risk of suicide, it seems that the worst problem is due to the withdraw process, when the drug can reach levels below the optimum for clinical management, causing suicidal ideation ${ }^{2,27-29}$.

Regarding taking suicidal drug overdose, a large nationwide population-based case-control study was performed in Taiwan. The authors found in 20,961 cases of SLE in comparison to 1,000,000 controls a higher risk of SDO in lupus that was 291:100,000 cases compared to $160: 100,000$ in controls and SDO was associated,in 
a multivariate analysis, with depression, insomnia and low income ${ }^{30}$.

\section{Suicidal Risk factors associated with SLE}

Concerning suicidal risk factors in lupus patients, there is an overlapping among the risks known to be present in the general population, and those nosology specific. The high risk for survivors of previous suicide attempts (more recent, more dangerous), as well as those in vulnerable social situation and having neuropsychiatric symptoms, specially cases of major, chronic, recurrent, or undertreated depression, psychosis, or schizophrenia, are also valid for patients with lupus. Chronic, recurrent, acute, unknown or undertreated psychiatric comorbidities increase the risk of suicidal behavior in this group of patients, and should be suspected when there are symptoms like sleep or appetite disorder, fatigue, alcohol and drug abuse, as well as resistance, irregular continuity, or abandoning of the established treatment. The difficulty in accessing mental health specialized treatment can also be considered as a risk fator ${ }^{2,6,7,10}$.

There are no consistent evidences in literature of autoimmune or non-specific inflammatory mechanisms associated to suicide risk in lupus patients, maybe due to the studies' methodologic limitations at that time. Not even the presence of $P$ autoantibody was recognized as a risk predictor. New study models that include suicide risk as a variable for cohort segments of lupus patients are necessary to better elucidate this matter ${ }^{2,10}$.

Genetic factor are also linked to suicide in SLE. In fact, the role of glutamate receptor gene polymorphisms in suicidal behaviour was evaluated in 130 SLE patients, and a significan association was found between suicidal ideation and the NR2A rs2072450 AC genotype polymorphism ${ }^{31}$.

Suicidal thoughts were present in $25 \%$ of patients with NPSLE, irrespective of sex, age, education, work status, disease duration and steroid treatment in a study with 53 lupus subjects. Moreover, suicidal ideation was connected with elevated levels of depression, anxiety and irritability ${ }^{32}$.

Periods of uncertainty regarding prognosis are also associated to a greater risk of suicide, which in lupus patients corresponds to the onset of the disease, as well as the phases of organ failure aggravation or treatment resistance, especially in neuropsychiatric cases where cognitive worsening is evidenced. The progression time is not as relevant regarding the control stage and, although there is no well-established connection between the disease activity indexes and suicide risk, it is likely that injuries in some target organs are more prone to induce suicide that in others. Cardiopulmonary complications with pleuritic pain, fatigue and dramatic reduction in functional capacity related to daily activities are heavily associated to suicide risks ${ }^{8-14}$.

In patients with SLE, the main suicide method is the abuse of the medication used for the treatment of their own comorbidities, like painkillers and psychoactive drugs. 2-8 That is why, to prevent suicide attempts, it is critical to provide information to patients and caregivers about the risks of the drug treatment, emphasizing the importance of following the prescribed dosage and the correct guidance regarding disposing the leftover pills. Health professionals should avoid providing large amounts of medicine to vulnerable patients, and should warn caregivers to restrict patients from accessing the medicine $e^{22,23,30}$.

Not always the person classified as high risk commits suicide, but the evaluation of this risk and the correct handling of these patients can reduce the occurrence of new cases, whereas new studies are still necessary to better specify the drivers of this process ${ }^{11-13}$.

\section{Assessment Tools}

If predicting when someone will commit suicide is almost impossible, it is possible to learn about and classify the risk factors that can play a role in the suicide and use this information into the decision making. Until recently, only epidemiological and statistics surveys were employed as tools for suicide tendency. Today, nonetheless, flourish attempts to outline the multiple information involved in this phenomenon in the form of standardized protocols and questionnaires to qualify the gravity of suicidal ideation and behavior. These instruments, in general, show high sensitivity and low specificity, and are useful for tracking risk groups within a population, but they do not prove adequate predictive values. Furthermore, they demand psychometric training for who administers them, and its format is impractical for daily usage in a $\mathrm{clinic}^{34-37}$.

To name only a few of the most well-known screening tools we can mention the Beck Scale Adapted for Suicide Ideation (BSS) ${ }^{38}$, the Suicide Behaviors Questionnaire-Revised (SBQ) $)^{39}$, Sheehan Suicidality Tracking Scale (S-STS) ${ }^{40}$, and the Columbia Suicide Severity Rating Scale (C-SSRS) ${ }^{41}$. The last one, especially in its reduced form, for not requiring the examiner to have mental health training, has been being used as standard in several international government agencies, as well as in its computerized version ${ }^{42}$.

\section{Clinical Management}

In each lupus patient visit it is necessary to look for signs of suicidal behavior, even if concealed by somatic complaints, by means of therapeutic listening, spoken approach, and risk factors evaluation. For this purpose, an inquiry with two blocks of three gradual questions should be added to the anamnesis: the first one for universal screening; and the second one, for selective approach of patients with suspected risk based on the initial responses ${ }^{6,7,41}$.

Although it is not possible to predict who is going to commit suicide, the health professional, even if not specialized in mental health, can evaluate the level of suicide risk and decide de proper handling for each case, rating the risk as low, medium or high. 
Low risk cases would be the ones where there is suicidal ideation, but no planning; medium risk cases would be the ones where there are the suicidal ideation and planning, but the person does not intend to execute them immediately; high risk cases are those where the patient has plans, opportunity and defined means, and indicates that the action is imminent, therefore, constitutes medical-psychiatric emergency ${ }^{2,41}$.

The recommended handling of patients considered prone to suicidal behavior goes from the basic, recommended for low risk cases, which includes therapeutic listening, acceptance and information about suicide protecting factors, binding to emotional support instruments like suicide prevention lifeline or support groups that can reduce isolation and discuss the suicidal thoughts in a way to offer options and reduce the tension. The doctor still must diagnose and treat the associated psychiatric disorders. If the symptoms persist, the doctor ought to arrange specialized mental health evaluation, always with the request of counter-reference ${ }^{6,7,43,44}$.

For the medium risk cases, patients must be sent as soon as possible to a psychiatric evaluation. Family members and friends must be contacted, after the patient's consent. It is necessary to invest in protective factors, block the patient's access to the means (firearms, knives, poison, and medicine), and guide the prevention to associated risks (not to ingest alcoholic beverages and other drugs, avoid high places and driving). The high-risk cases must be treated as psychiatric emergencies. It is essential to increase attention to the space and to reduce risks, establishing from the first moment a safe room for the medical care cr,42,43. $^{7}$.

The patient in this stage cannot be left alone at anytime, and the transportation to a psychiatric emergency room is only allowed by ambulance, never by individual means or nonprofessionals. In turn, the emergency rooms will be responsible for reducing the immediate risk, hospitalization is recommended during a crisis, and for mental health monitoring. It is important to act addressing the suicide attempt survivors, their family members and friends, as well as their community. The quaternary prevention is important to avoid new attempts ${ }^{11,13}$.

Technology solutions in detecting and preventing cases can be useful instruments. For example: data systems that can cross reference personal health records; intelligent machines that can analyze the answers from the evaluation instruments using voice recognition patterns; analysis tools incorporated to the patient's electronic records capable of treating data, evaluate suicide data, generate warnings and suggest actions to be taken by the doctors; as well as multiplying interactive solutions like camera surveillance, crisis sensors and alert systems; daily monitoring by electronic messages and applications for smartphones. These solutions can be useful, but they can still not offer comprehensive results that can replicate the human support between people in risk and their support agents $^{44-47}$.

\section{CONCLUSION}

Suicidal behavior is more frequent in SLE than we recognize, and developing new strategies for assessing the risk factors and including handling protocols for the medical practice, even for non-psychiatrists, is essential to reduce its persistence and evolution. Special attention must be given to high-risk patients, not only the ones who reveal ideation and plans to commit suicide, but also the ones who survived recent attempts, whose risk of new attempts, despite an appearing post crisis improvement, can be even greater.

The coordination between the studies about suicidal behavior and its complex network of individual and sociocultural factors with the studies on this multisystem autoimmune disease with a wide manifestation spectrum, which is lupus, creates a new and important field of research, where new studies can clarify the clinical interrelationships and increase the predictive value of specific evaluation tolls.

\section{REFERENCES}

1.BERTOLOTE, J. M. The suicide and its prevention. São Paulo: UNIFESP, 2012.

2.KARASSA, F.B.; MAGLIANO, M.; ISENBERG, D. A. Suicide attempts in patients with systemic lupus erythematosus. Ann rheum dis., London, v. 62, n.1, p. 58-60, 2003

3. DURKHEIM, E. The suicide. São Paulo: Martin Claret, 2005.

4. FRANKL, V.E. The will to meaning: foundations and applications of logotherapy. São Paulo: Paulus, 2011.

5. BOTEGA, N.J. et al.Suicidal behavior in the community: prevalence and factors associated with suicidal ideation. Rev bras psiquiatr., São Paulo, v. 27, n. 1, p. 45-53, 2005.

6. WORLD HEALTH ORGANIZATION. Preventing suicide: a global imperative. Geneva: WHO Library, 2014.

7. BRAZILIAN ASSOCIATION OF PSYCHIATRY AND FEDERAL COUNCIL OF MEDICINE. Suicide: reporting to prevent. Brasilia: FCM/BAP, 2014. p. 53.

8. FUTRELL, N.; SCHULTZ, L.R.; MILLIKAN, C. Central nervous system disease in patients with systemic lupus erythematosus. Neurology, New York, v. 42, n. 9, p.1649-1657, 1992.

9. JARPA, E. et al. Common mental disordersand psychological distress in systemic lupus erythematosus are not associated with disease activity. Lupus, Houndmills, v. 20 n.1, p. 58-66, 2011.

10. ASANO, N. M. J. et al. Comorbidades psiquiátricas em pacientes com lúpus eritematoso sistêmico: uma revisão sistemática dos últimos 10 anos. Rev bras reumatol.,Campinas, v. 53, n.5, p. 431-437, 2013.

11. HARRIS, E.C.; BARRACLOUGH, B.M. Suicide as an outcome for medical disorders. Medicine, Baltimore, v. 73, n. 6, p. 281-296, 1994.

12. ISHIKURA, R.; MORIMOTO, N.; TANAKA, K. Factors associated with anxiety, depression and suicide ideation in female outpatients with SLE in Japan. Clin rheumatol., Brussels, v. 20 n. 6, p. 394-400, 2001.

13. ZAKERI, Z. et al. Prevalence of depression and depressive symptoms in patients with systemic lupus erythematosus: Iranian experience. Rheumatol int., Berlin, v.32, p.1179-1187, 2012. 
14. MOK, C. C. et al. Suicidal ideation in patients with systemic lupus erythematosus: incidence and risk factors. Rheumatology, Basel, v.53, n. 4, p.714-721, 2014.

15. XIE, L. F. et al. Prevalence and correlates of suicidal ideation in SLE inpatients: chinese experience. Rheumatol int., Berlin, v. 32, n.9, p.2707-2714, 2012.

16. BERTOLOTE, J. M. et al. Suicide attempts, plans, and ideation in culturally diverse sites: the WHO SUPRE-MISS community survey. Psychol Med., London, v.35, n.10, p.1457-1465, 2005.

17.FRASQUILHO, D. et al. Mental health outcomes in times of economic recession: a systematic literature review. BMC Public. Health, London, v.16, p.115, 2016.

18. MOREIRA, L. C. O.; BASTOS, P.R.H.O. Prevalence and factors associated with suicidal ideation in adolescence: literature review. School Educat Psychol., [s.I], v.19, n.3, p. 445-453, 2015.

19. VASCONCELOS-RAPOSO, J. et al. Levels of suicidal ideation in young adults. Psychology Studies, [s.I], v. 33, n.2, p.345-354, 2016.

20. CIPRIANI, A. et al. Lithium in the prevention of suicide in mood disorders: updated systematic review and meta-analysis. BMJ, London, v. 27, p. 346:f3646, 2013. Disponível em: http://www.bmj. com/content/346/bmj.f3646. Acesso em: 27 jun. 2013. DOI: 10.1136/ bmj.f3646.

21. JAGODIC, H. K.; AGIUS, M.; PREGELJ, P. Psychopharmacotherapy prescription and suicidal behaviour. Psychiatr Danub., Zagreb, v. 25, suppl. 2, p. S324-8, 2013. Disponivel em: http:// www.hdbp.org/psychiatria_danubina/pdf/dnb_vol25_sup2/dnb_ vol25_sup2_324.PDF. Acesso em: 27 jun. 2013.

22. FAWCETT, J. A. et al. Definition and management of suicidality in psychiatric patients. J clin psychiatry, Memphis, v. 70, n.10, p.e38, 2009.

23. LAVIGNE, J. E. et al. Utilization of prescription drugs with warnings of suicidal thoughts and behaviours in the USA and the US Department of Veterans Affairs, 2009. J. pharm. health serv. res., Chichester, v.3, p.157-163, 2012.

24. PEREIRA, A. et al. Suicidality associated with antiepileptic drugs: implications for the treatment of neuropathic pain and fibromyalgia. Pain, Amsterdam, v. 154, n.3, p. 345-349, 2013.

25. APOSTOLOVA, N. et al. Efavirenz and the CNS: what we already know and questions that need to be answered. J. antimicrob. chemother., London, v. 70, n.10, p.2693-2708, 2015.

26. MADEIRA, N. et al. Isotretinoin, Depression and Suicide. Rev. psiquiatr. clín., São Paulo, v. 39, n. 2, p. 76-77, 2012.

27. VOAKLANDER, D. C. et al. Medical illness, medication use and suicide in seniors: a population-based case-control study. J. Epidemiol. Com. Health, [S.I.], v. 62, n.2, p.138-146, 2008.

28. FARDET, L.; PETERSEN, I.; NAZARETH, I. Suicidal behavior and severe neuropsychiatric disorders following glucocorticoid therapy in primary care. Am. J. Psychiatr., Estados Unidos, v.169, n. 5, p.491-497, 2012.

29. FARDET, L. et al. Severe neuropsychiatric outcomes following discontinuation of long-term glucocorticoid therapy: a cohort study. J.clin. psychiatr., Memphis, v.74, n.4, p.e281-286, 2013.

30. TANG, K.T. et al. Suicidal drug overdose in patients with systemic lupus erythematosus, a nationwide population-based case-control study. Lupus, Houndmills, v. 25, n. 2, p. 199-203, 2016.
31. BUII, R. I. et al. Suicidal ideation in systemic lupus erythematosus: NR2A gene polymorphism, clinical and psychosocial factors. Lupus, Houndmills, p. 961203317742711 , Jan 12017

32. HAJDUK, A. et al. Prevalence and correlates of suicidal thoughts in patients with neuropsychiatric lupus. Lupus, Houndmills, v. 25, n. 2, p. 185-92, Feb 2016.

33. SARCHIAPONE, M. et al. Controlling access to suicide means. Int. j. environ. res. public. health, Basel, v. 8, n.12, p. 4550-4562, 2011.

34. GOLDSTEIN, R. B. et al. The prediction of suicide. sensitivity, specificity, and predictive value of a multivariate model applied to suicide among 1906 patients with affective disorders. Arch. gen. psychiatr, Chicago, v. 48, n.5, p. 418-422, 1991.

35. PARIS, J. Predicting and preventing suicide: do we know enough to do either? Harvard. rev. psychiatry, St. Louis, v.14, n. 5, p. 233-240, 2006.

36. LARGE, M. M.; RYAN, C. J. Suicide risk assessment: Myth and reality. Int. J. Clin. Pract., Oxford, v. 68, n. 6, p. 679-681, 2014.

37. HANEY, E. M. et al. Suicide risk factors and risk assessment tools: a systematic review. Washington (DC): Department of Veterans Affairs, 2012.

38. BECK, A. T.; KOVACS, M.; WEISSMAN, A. Assessment of suicidal intention: the Scale for Suicide Ideation. J. consult. clin. psycho., Washington, v. 47, n.2, p.343-352, 1979.

39. OSMAN, A. et al. The Suicidal Behaviors Questionnaire-Revised $(S B Q-R)$ : validation with clinical and nonclinical samples. Assessment, Odessa, v. 8, p.443-454, 2001.

40. SHEEHAN, D. V.; GIDDENS, J. M.; SHEEHAN, I.S. Status update on the sheehan-suicidality tracking scale (S-STS) 2014 Innov. clin. neurosci, Edgemont, v.11, n. 9-10, p. 93-140, 2014.

41. POSNER, K. et al. The Columbia-suicide severity rating scale: initial validity and internal consistency findings from three multisite studies with adolescents and adults. Am. j. psychiatry, Arlington, v.168, n.12, p.1266-1277, 2011.

42. MUNDT, J. C. et al. Feasibility and validation of a computer-automated Columbia-Suicide severity rating scale using interactive voice response technology. J. psychiatr. res., Oxford, v. 44, n.16, p.1224-1228, 2010.

43. FLEISCHMANN, A. et al. Effectiveness of brief intervention and contact for suicide attempters: a randomized controlled trial in five countries. Bull. World. Health. Organ, Geneve, v. 86, n.9, p.703-709, 2008.

44. HAUPT, M. et al. Improvement of coping abilities in patients with systemic lupus erythematosus: a prospective study. Ann. Rheum. Dis, London, v. 64, p.1618-1623, 2005.

45. VAHABZADEH, A.; SAHIN, N.; KALALI, A. Digital suicide prevention: can technology become a game-changer? Innov. clin. neurosci., Edgemont, v.13, n.5-6, p.16-20, 2016.

46. LARSEN, M.E.; NICHOLAS, J.; CHRISTENSEN, H. A. Systematic Assessment of Smartphone Tools for Suicide Prevention. PLos One [Internet], San Francisco, v.11, n. 4, p.e0152285, 2016. Disponivel em: https://www.ncbi.nlm.nih.gov/pmc/articles/PMC4830444/. Acesso em:25 jun. 2013. DOI: 10.1371/journal.pone.0152285.

47. AUDEMARD-VERGER, A. et al. Is it relevant to screen young women hospitalized in psychiatric department for neuropsychiatric systemic lupus erythematosus (NPSLE)?: A prospective study of 100 psychiatric inpatients. Medicine, Baltimore, v. 95, n. 47, p. e5288, Nov 2016.

Submetido em: 02/10/2017

Aceito em: 05/10/2020 